\title{
Rice bran protein-based films enriched by phenolic extract of fermented rice bran and montmorillonite clay
}

\section{Películas a base de proteínas de salvado de arroz enriquecidas por el extracto fenólico de salvado de arroz fermentado y por la arcilla montmorillonítica}

\author{
Cristiano G. Schmidt ${ }^{\mathrm{a} *}$, Miguel A. Cerqueira ${ }^{\mathrm{b}}$, António A. Vicente ${ }^{\mathrm{b}}$, José A. Teixeira ${ }^{\mathrm{b}}$ and Eliana B. Furlong ${ }^{\mathrm{a}}$ \\ ${ }^{a}$ Escola de Química e Alimentos, Universidade Federal do Rio Grande, Rio Grande-RS 96203-900, Brazil; ${ }^{b}$ Centre of Biological \\ Engineering, Universidade do Minho, Braga, 4710-057, Portugal
}

(Received 17 March 2014; final version received 26 June 2014)

\begin{abstract}
Proteins extracted from rice bran were used to prepare bio-base films where a factorial experimental design was performed in order to evaluate the effect of protein and glycerol concentrations, and the addition of phenolic extract and montmorillonite (MMT) clay on their physicochemical properties. The phenolic extract was obtained from fermentation of rice bran in solid state with the fungus Rhizopus oryzae. Results showed that protein concentration affected $(p<0.05)$ the luminosity, opacity and solubility of the films. An increase of glycerol concentration strongly affects $(p<0.05)$ the values of mechanical properties and water vapor permeability of the films. The addition of phenolic extract to the films affected $(p<0.05)$ opacity, tensile strength, elongation, Young's modulus and water vapor permeability, while addition of MMT decreased $(p<0.05)$ the mechanical properties of the films. Films presented solubility values of less than $25 \%$, luminosity above $80\left(L^{*}\right)$, opacity above $14 \%$, tensile strength of $8.6 \mathrm{MPa}$, elongation of $70 \%$, elasticity above $600 \mathrm{MPa}$ and water vapor permeability of $7.5 \mathrm{~g} . \mathrm{mm} / \mathrm{d} \cdot \mathrm{m}^{2} . \mathrm{kPa}$. These results show that rice bran protein can be used in the production of bio-based films to further use in food applications.
\end{abstract}

Keywords: rice bran; protein; phenolic extract; montmorillonite clay; bio-based films

Con el fin de evaluar el efecto que sobre las propiedades fisicoquímicas de las proteínas extraídas del salvado de arroz tienen distintas concentraciones de proteína y de glicerol, así como la adición de extracto fenólico y de arcilla montmorillonítica, las mismas se utilizaron para preparar películas de base biológica en el marco de un diseño experimental factorial. Mediante la fermentación de salvado de arroz en estado sólido con el hongo Rhizopus oryzae, se obtuvo el extracto fenólico. Los resultados demuestran que la concentración proteica afectó significativamente $(p<0,05)$ la luminosidad, la opacidad y la solubilidad de las películas. Asimismo, un aumento de la concentración de glicerina afectó fuertemente $(p<0,05)$ los valores de las propiedades mecánicas y de la permeabilidad al vapor de agua de las mismas. La adición de extracto fenólico a las películas afectó de manera significativa $(p<0,05)$ la opacidad, la fuerza de tensión, el alargamiento, el módulo de Young y la permeabilidad al vapor de agua, mientras que la adición de montmorillonita disminuyó $(p<0,05)$ sus propiedades mecánicas. Se constató que las películas mostraron valores de solubilidad inferiores a 25\%, de luminosidad superiores a 80 ( $\mathrm{L}^{*}$ ), de opacidad superiores a $14 \%$, de fuerza de tensión de $8,6 \mathrm{MPa}$, de alargamiento de $70 \%$, de elasticidad superiores a 600 MPa y de permeabilidad al vapor de agua de $7,5 \mathrm{~g} . \mathrm{mm} / \mathrm{d} . \mathrm{m}^{2} . \mathrm{kPa}$. Estos resultados demuestran que, en el ámbito de los alimentos, la proteína de salvado de arroz puede utilizarse para la producción de películas de base biológica con el fin de adjudicarle usos adicionales.

Palabras claves: salvado de arroz; proteína; extracto fenólico; arcilla montmorillonítica; películas de base biológica

\section{Introduction}

Edible films can be used as semipermeable barriers in food with various purposes, such as: control respiration rate, retard moisture loss and color variation, improve texture and mechanical integrity, help retaining flavor and inhibit growth of micro-organisms (Olivas \& Barbosahy-Canovas, 2009). Thus, development of edible or biodegradable films arises from the demand for high quality and safe food, as well as from environmental concerns with the disposal of non-renewable materials. It is also an opportunity to create a new market of raw materials for packaging (Fakhouri et al., 2007).

Proteins of plant origin are more often used than animal proteins for films' production due to availability and lower cost (Adebiyi, Adebiyi, Jin, Ogawa, \& Muramoto, 2008; Rojas-Grau, Soliva-Fortuny, \& Martín-Belloso, 2009). The byproducts from the cereal agro-industrial processing may be a source of protein that can be recovered for the production of protein-based films. An example is rice bran, resulting from the processing of the grain, which proteins were extracted to produce bio-based films (Adebiyi et al., 2008; Cipolatti et al., 2012; Oliveira et al., 2011).

The choice of film-forming materials will depend on the purpose, the nature of the product and the particular application sought. In the case of proteins, they require the use of plasticizers to improve processability, strength and elasticity of the films, being glycerol one of the most used plasticizers (Adebiyi et al., 2008; Cao, Fu, \& He, 2007; Dangaran, Tomasula, \& Qi, 2009).

Organic-inorganic hybrid systems, particularly those in which silicates are dispersed in a polymeric matrix, have been used in the formulation of films to improve their properties. MMT, characterized by its moderate negative surface charge (Tunc et al., 2007), has been included in the formulation of bio-based films and showed to improve mechanical strength, heat resistance and barrier properties of films (Chen \& Zhang, 2006; Martins et al., 2012).

In addition, bio-based films have a great potential to carry active ingredients such as anti-browning agents, colorants, 
flavors, nutrients, spices and antimicrobial compounds that may extend shelf life reducing the risk of pathogens growth on food surfaces (Rojas-Grau et al., 2009). Phenolic compounds from rice bran fermentation have high antioxidant and antimicrobial activity (Oliveira, Dors, Souza-Soares, \& Furlong, 2007; Souza, Oliveira, Rocha, \& Furlong, 2010) with potential to be applied in the preparation of edible films. This study evaluated the effect of glycerol, phenolic extract and MMT clay on the physicochemical properties of films of protein obtained from rice bran.

\section{Materials and methods}

\section{Rice bran protein concentrate (RBPC) extraction}

Rice bran was provided by companies in Rio Grande do Sul (Brazil). The protein concentrate used in films preparation was obtained from rice bran using the methodology adapted from Adebiyi et al. (2008). The rice bran samples (particle size 32 mesh) were degreased using petroleum ether (three times in the ratio $1: 7 \mathrm{w} / \mathrm{v}$ ) under orbital shaking at $100 \mathrm{rpm}$ for $1 \mathrm{~h}$ at $25^{\circ} \mathrm{C}$. After evaporation of excess petroleum ether (oven with air circulation at $40^{\circ} \mathrm{C}$ for $30 \mathrm{~min}$ ), defatted rice bran was subjected to protein extraction in an alkaline medium ( $\mathrm{pH}$ adjusted to 11.5 with $0.1 \mathrm{~mol} / \mathrm{L} \mathrm{NaOH}$ solution in the ratio $1: 10 \mathrm{w} / \mathrm{v}$ for $30 \mathrm{~min}$ at $25^{\circ} \mathrm{C}$ ) using an orbital shaking at $200 \mathrm{rpm}$. After centrifugation $\left(15,200 \mathrm{~g}, 30 \mathrm{~min}, 10^{\circ} \mathrm{C}\right)$, the supernatant was collected and the residue submitted to a second extraction. The supernatants from both extractions were pooled and the extracted proteins were precipitated by adjusting the solution $\mathrm{pH}$ to 4.5 with a solution of $0.1 \mathrm{~mol} / \mathrm{L} \mathrm{HCl}$. After standing overnight at $4^{\circ} \mathrm{C}$, the proteins were separated by centrifugation $\left(15,200 \mathrm{~g}, 30 \mathrm{~min}, 10^{\circ} \mathrm{C}\right)$, followed by washing the precipitate with distilled water. The protein concentrate was stored at $-18^{\circ} \mathrm{C}$ until the physicochemical characterization and application. The quantification of protein $\left(n^{\circ}\right.$ 955.04C; conversion factor of 5.7), lipid ( $\left.{ }^{\circ} 920.85\right)$, ash $\left(\mathrm{n}^{\circ} 900.02 \mathrm{~A}\right)$ and total fiber $\left(\mathrm{n}^{\circ} 962.09\right)$ were determined according to the AOAC method (2000) and total carbohydrates estimated by difference.

\section{Phenolic extract}

The phenolic extract was obtained from solid-state fermentation of rice bran with the fungus Rhizopus oryzae (CCT 1217) according to the method proposed by Oliveira et al. (2011). Rice bran samples were incubated with a solution of $4 \times 10^{6}$ spores $/ g$ of bran in trays $(12 \mathrm{~cm} \times 8 \mathrm{~cm} \times 4 \mathrm{~cm})$ for $96 \mathrm{~h}$ at $30^{\circ} \mathrm{C}$, whereas $45 \mathrm{~mL}$ of a nutrient solution $\left(2 \mathrm{~g} / \mathrm{L}\right.$ of $\mathrm{KH}_{2} \mathrm{PO}_{4}$, $1 \mathrm{~g} / \mathrm{L}$ of $\mathrm{MgSO}_{4}$ and $\left.5 \mathrm{~g} / \mathrm{L}\left(\mathrm{NH}_{4}\right)_{2} \mathrm{SO}_{4}\right)$ was added for each $100 \mathrm{~g}$ of bran. The humidity of the medium was adjusted to $50 \%$ with sterile distilled water.

The phenolic compounds from fermented rice bran were extracted with methanol at the ratio 1:10 (w/v), according to the method described by M. Souza et al. (2010); $5 \mathrm{~g}$ aliquots were subjected to orbital shaking $(150 \mathrm{rpm})$ for $3 \mathrm{~h}$ with methanol and filtered to obtain a crude extract that was subjected to a partition with $10 \mathrm{~mL}$ hexane ( 3 times). The organic solvent was evaporated on a rotary-evaporator at $50^{\circ} \mathrm{C}$ under reduced pressure and the phenolic compounds were resuspended with distilled $(10 \mathrm{~mL})$ water in an ultrasonic bath for $10 \mathrm{~min}$. The resulting extract was clarified with $5 \mathrm{~mL}$ of $0.1 \mathrm{M} \mathrm{ZnSO}_{4}$ and $5 \mathrm{~mL} \mathrm{Ba}(\mathrm{OH})_{2} 0.1 \mathrm{~mol} / \mathrm{L}$ and allowed to rest for $20 \mathrm{~min}$. After centrifugation $\left(3200 \mathrm{~g}, 10 \mathrm{~min}, 25^{\circ} \mathrm{C}\right.$ ) the supernatant containing the phenolic compound was collected, lyophilized and quantified spectrophotometrically at $750 \mathrm{~nm}$ with Folin-Ciocalteau reagent using a standard curve of ferulic acid (2-20 mg).

\section{Experimental design and effects analysis}

The RBPC was used as the matrix for protein- films preparation being glycerol used as plasticizer. Phenolic compounds derived from rice bran fermentation and MMT were used as additives. A $2^{4}$ factorial experimental design was performed to determine the effect of the concentration of each component in the films properties (Table 1). The results were evaluated by analysis of effects and response surface using Statistica 7.0 software. Response surfaces that showed a correlation coefficient $(R)$ greater than 0.9 and calculated $F$ value for the mathematical model of at least two times higher than that of Fisher's $F$ were generated, considering only the significant effects $(p<0.05)$ in each property.

\section{Preparation of films}

The RBPC obtained from rice bran and the phenolic extract (PE) obtained from rice bran fermentation were used in films' preparation, together with glycerol and MMT clay. The RBPC was resuspended in alkaline medium using a solution of $0.1 \mathrm{~mol} / \mathrm{L}$ $\mathrm{NaOH}$ and adjusted to $\mathrm{pH} 10$. The solution was heated to $85^{\circ} \mathrm{C}$ and the glycerol and MMT (pre-hydrated with distilled water for $16 \mathrm{~h}$ before being added) added keeping the mixture under stirring $(150 \mathrm{rpm})$ for $30 \mathrm{~min}$. The mixture was cooled to $40^{\circ} \mathrm{C}$ before addition of the phenolic extract and kept under magnetic stirring for $10 \mathrm{~min}$ and then was kept in an ultrasonic bath for 5 min to remove air bubbles. The films were casted by adding $20 \mathrm{~mL}$ of film solution in polystyrene Petri dishes $(9 \mathrm{~cm}$ diameter) and dried in an oven with circulating air at $30^{\circ} \mathrm{C}$ for approximately $24 \mathrm{~h}$. The films were kept in a desiccator containing a saturated solution of $\mathrm{NaBr}(58 \% \mathrm{RH})$ for $96 \mathrm{~h}$ before testing.

\section{Characterization of the films \\ Solubility}

Film samples with $2 \mathrm{~cm}$ diameter were dried at $105^{\circ} \mathrm{C}$ until constant weight, and then they were subsequently immersed in $50 \mathrm{~mL}$ distilled water and subjected to orbital shaking (70 rpm) at $25^{\circ} \mathrm{C}$ for $24 \mathrm{~h}$. After this, samples were filtered on porous crucible with glass wool and dried to constant weight at $105^{\circ} \mathrm{C}$. Solubility was determined by weight difference between the dry

Table 1. Levels of the independent variables used in experimental design.

Tabla 1. Niveles de las variables independientes usadas en el diseño experimental.

\begin{tabular}{lrrr}
\hline & \multicolumn{3}{c}{ Levels } \\
\cline { 2 - 4 } Factor & \multicolumn{1}{c}{1} & 0 & +1 \\
\hline Protein $(\mathrm{g} / \mathrm{L})$ & 20 & 30 & 40 \\
Glycerol $\left(\mathrm{g} / \mathrm{kg}_{\text {protein }}\right)$ & 200 & 300 & 400 \\
PE $\left(\mathrm{g} / \mathrm{kg}_{\text {protein }}\right)$ & 0 & 20 & 40 \\
MMT $\left(\mathrm{g} / \mathrm{kg}_{\text {protein }}\right)$ & 0 & 50 & 100 \\
\hline
\end{tabular}

Note: PE, phenolic extract; MMT, montmorillonite clay. 
mass that was not solubilized in water and the initial mass. Three replicates were obtained for each film.

\section{Optical properties}

Luminosity $\left(\mathrm{L}^{*}\right)$ and opacity $(\mathrm{Op})$ parameters were determined using a Minolta colorimeter. Films' samples were overlapped to a white standard $(Y=93.5, x=0.3114, y=0.3190)$ for the measurement of luminosity. Opacity was calculated as the ratio of film opacity superimposed on a standard black and a standard white, as proposed by Carvalho and Grosso (2006), according to Equation (1):

$$
\mathrm{Op}(\%)=\frac{P_{\text {Black }}}{P_{\text {White }}} \times 100
$$

where: $\mathrm{Op}=$ opacity; $P_{\text {Black }}=Y$ coordinate value in black standard, $P_{\text {White }}=Y$ coordinate value of the white standard. Tests were replicated at least six times for each film.

\section{Mechanical properties}

The tensile strength (TS) and percent elongation (\%E) of films were obtained from the force deformation curves determined using a texturometer (TA.XT plus, Stable Micro Systems, Godalming, England) operating according to the standard method D882-02 (ASTM, 2001), with an initial separation of the jaws of $50 \mathrm{~mm}$ and a testing speed of $100 \mathrm{~mm} / \mathrm{min}$. The films were cut to form specimens of $80 \mathrm{~mm}$ long and $25 \mathrm{~mm}$ wide. The Young's modulus (YM) was calculated from the tangent of the initial linear portion of the stress-strain plot (Cao et al., 2007). TS, $\% E$ and YM tests were replicated at least five times for each type of film. Film thickness was measured using a digital micrometer (Insize, IP54, São Paulo, Brazil) with a sensitivity of $0.001 \mathrm{~mm}$.

\section{Water vapor permeability}

The water vapor permeability (WVP) of the films was determined using an adaptation of the methodology proposed by Andreuccetti, Rosemary, Galicia-García, Martínez-Bustos, and Grosso (2011). Approximately $10 \mathrm{~g}$ of $\mathrm{CaCl}_{2}(0 \% \mathrm{RH})$ were placed in polystyrene containers (area $=18.85 \mathrm{~cm}^{2}$ ), sealed with the films and placed in a desiccator containing a saturated solution of $\mathrm{NaCl}(75 \% \mathrm{RH})$ at $25^{\circ} \mathrm{C}$ (films had initial moisture content of $149 \pm 32 \mathrm{~g} / \mathrm{Kg}$ ). Every $24 \mathrm{~h}$ during 7 days the weight of the containers was taken. The water vapor transmission rate (WVTR) of the films was determined by the angular coefficient of the weight gain curve of water versus time. WVP was determined according to Equation (2):

$$
\mathrm{WVP}=\operatorname{WVTR}\left(\frac{x}{\Delta P}\right)
$$

where: WVTR $=$ water vapor transmission rate, $x=$ thickness; $\Delta P=$ partial vapor pressure difference. Three replicates were obtained for each film.

\section{Scanning electron microscopy}

The surface morphology of the films was examined using scanning electron microscopy (SEM) (Nova NanoSEM 200, Eindhoven, The Netherlands). Film samples, after drying and the stabilization process (described in Preparation films section), were mounted on aluminum base using carbon tape and coated by gold sputtering (approximately $10 \mathrm{~nm}$ in thickness).

\section{Fourier-transform infrared (FTIR) spectroscopy}

The infrared spectrum of the films was determined using the Infrared Fourier transform (Perkin-Elmer 16 PC spectrometer, Boston, USA) using the attenuated total reflectance technique and spectral analysis in the range between 4000 and $600 \mathrm{~cm}^{-1}$ using 16 scans. Signal averages were obtained at a resolution of $4 \mathrm{~cm}^{-1}$.

\section{Results and discussion \\ Characterization of the raw material}

Rice bran, a by-product of rice processing, was extracted and used as main material for the production of bio-based films production. Table 2 shows rice bran and rice bran concentrate composition. Results show that rice bran has the protein content above $165 \mathrm{~g} / \mathrm{kg}$. RBPC was obtained from rice bran with protein content above $700 \mathrm{~g} / \mathrm{kg}$ (dry basis).

The phenolic content increased about $80 \%$ during fermentation (Table 2). Phenolic compounds contained in cell walls of rice bran are linked to carbohydrates and lignin (Pourali, Asghari, \& Yoshida, 2010) that during fermentation are released from structural rice bran by the action of microorganisms (Schmidt \& Furlong, 2012). Phenols are prevalent in rice phenolic acids, mainly ferulic and $p$-coumaric acid, which have high antioxidant and antimicrobial activities (Schmidt, Gonçalves, Prietto, Hackbart, \& Furlong, 2014; M. Souza et al., 2010), thus providing a potential ingredient for use in edible films.

\section{Experimental design}

Tables 3 and 4 showed that films properties are strongly affected by the materials used to prepare the film forming solution. Data obtained from experimental design were fitted as a function of the dependent variables that presented statistical significant effects $(p<0.05)$. To verification of mathematical models generated for each property, an analysis of variance (ANOVA) was performed (Table 5). The response surfaces were generated for WVP, opacity, YM and TS (Figure 1) that presented statistically significant models (Montgomery, 1991). Solubility showed a low variation explained by model, below $67 \%$, while the luminosity although had an $F$ ratio value high and a variance of $88 \%$, being the protein concentration factor the only significant $(p<0.05)$ factor.

Table 2. Composition of rice bran and rice bran protein concentrated on dry basis.

Tabla 2. Composición del salvado de arroz y del concentrado de proteína de salvado de arroz con base seca.

\begin{tabular}{lcc}
\hline Component $(\mathrm{g} / \mathrm{kg})$ & $\mathrm{RB}$ & $\mathrm{RBPC}$ \\
\hline Protein & $164.9 \pm 6.9$ & $716.7 \pm 53.2$ \\
Lipids & $188.6 \pm 6.1$ & $5.2 \pm 3.1$ \\
Ash & $94.1 \pm 1.0$ & $29.2 \pm 3.3$ \\
Carbohydrate & $552.6 \pm 10.5$ & $249.0 \pm 39.8$ \\
Phenolic content & $\mathrm{RB}$ & $\mathrm{RBF}$ \\
$\mathrm{g} / \mathrm{kg}$ & $2.41 \pm 0.01$ & $4.33 \pm 0.06$ \\
\hline
\end{tabular}

Note: Values are expressed as means $\pm \mathrm{SD}$. RB, rice bran; RBPC, rice bran protein concentrated; RBF, rice bran fermented. 
Table 3. Values of solubility, lightness, opacity, tension strength, elongation, Young's modulus and water vapor permeability for each film formulation.

Tabla 3. Valores de solubilidad, de ligereza, de opacidad, de fuerza de tensión, de alargamiento, de los módulos de Young y de permeabilidad al vapor de agua para cada fórmula de película.

\begin{tabular}{|c|c|c|c|c|c|c|c|c|c|c|c|}
\hline & {$[\mathrm{P}]$} & {$[\mathrm{G}]$} & {$[\mathrm{PE}]$} & [MMT] & Solubility & Lightness & Opacity & $\mathrm{TS}$ & Elongation & YM & WVP \\
\hline Sample & $\mathrm{g} / \mathrm{L}$ & $\mathrm{g} / \mathrm{kg}_{\text {protein }}$ & $\mathrm{g} / \mathrm{kg}_{\text {protein }}$ & $\mathrm{g} / \mathrm{kg}_{\text {protein }}$ & $\%$ & $\mathrm{~L}^{*}$ & $\%$ & $\mathrm{MPa}$ & $\%$ & $\mathrm{MPa}$ & g.mm/d.m $\mathrm{m}^{2} \cdot \mathrm{kPa}$ \\
\hline 1 & $-1(20)$ & $-1(200)$ & $-1(0)$ & $-1(0)$ & $37.2 \pm 3.1$ & $76.9 \pm 0.8$ & $18.1 \pm 1.5$ & $5.2 \pm 0.2$ & $26.1 \pm 3.7$ & $216.0 \pm 81.4$ & $7.7 \pm 0.2$ \\
\hline 2 & $1(40)$ & $-1(200)$ & $-1(0)$ & $-1(0)$ & $24.7 \pm 0.8$ & $61.6 \pm 4.7$ & $26.5 \pm 2.0$ & $6.5 \pm 1.0$ & $7.8 \pm 0.9$ & $218.6 \pm 31.3$ & $10.2 \pm 1.2$ \\
\hline 3 & $-1(20)$ & $1(400)$ & $-1(0)$ & $-1(0)$ & $29.4 \pm 2.5$ & $81.0 \pm 2.4$ & $15.5 \pm 1.0$ & $3.3 \pm 0.5$ & $29.0 \pm 0.2$ & $84.5 \pm 4.1$ & $11.7 \pm 1.2$ \\
\hline 4 & $1(40)$ & $1(400)$ & $-1(0)$ & $-1(0)$ & $30.1 \pm 0.4$ & $63.9 \pm 3.8$ & $23.3 \pm 1.7$ & $4.3 \pm 0.2$ & $52.7 \pm 4.2$ & $98.7 \pm 2.3$ & $17.1 \pm 0.4$ \\
\hline 5 & $-1(20)$ & $-1(200)$ & $1(40)$ & $-1(0)$ & $36.0 \pm 1.7$ & $77.7 \pm 4.3$ & $15.4 \pm 1.5$ & $8.6 \pm 1.9$ & $1.6 \pm 0.9$ & $617.5 \pm 97.4$ & $10.6 \pm 0.3$ \\
\hline 6 & $1(40)$ & $-1(200)$ & $1(40)$ & $-1(0)$ & $31.6 \pm 2.1$ & $66.3 \pm 3.6$ & $19.6 \pm 1.7$ & $6.9 \pm 0.7$ & $0.8 \pm 0.2$ & $551.9 \pm 94.3$ & $10.4 \pm 0.2$ \\
\hline 7 & $-1(20)$ & $1(400)$ & $1(40)$ & $-1(0)$ & $36.4 \pm 1.3$ & $80.1 \pm 2.5$ & $14.1 \pm 1.4$ & $3.3 \pm 0.6$ & $33.4 \pm 4.2$ & $51.3 \pm 2.4$ & $11.8 \pm 1.1$ \\
\hline 8 & $1(40)$ & $1(400)$ & $1(40)$ & $-1(0)$ & $34.5 \pm 1.5$ & $65.3 \pm 4.3$ & $20.1 \pm 1.7$ & $2.3 \pm 0.2$ & $56.8 \pm 6.9$ & $41.1 \pm 4.1$ & $21.3 \pm 1.1$ \\
\hline 9 & $-1(20)$ & $-1(200)$ & $-1(0)$ & $1(100)$ & $33.7 \pm 1.0$ & $80.5 \pm 2.6$ & $16.3 \pm 1.4$ & $3.1 \pm 0.1$ & $17.9 \pm 1.1$ & $57.7 \pm 11.6$ & $7.5 \pm 0.5$ \\
\hline 10 & $1(40)$ & $-1(200)$ & $-1(0)$ & $1(100)$ & $28.1 \pm 0.7$ & $60.2 \pm 5.6$ & $26.9 \pm 3.5$ & $5.8 \pm 0.7$ & $4.9 \pm 2.3$ & $147.4 \pm 3.2$ & $9.3 \pm 0.9$ \\
\hline 11 & $-1(20)$ & $1(400)$ & $-1(0)$ & $1(100)$ & $40.2 \pm 5.1$ & $80.2 \pm 1.7$ & $15.4 \pm 1.1$ & $1.5 \pm 0.1$ & $31.2 \pm 4.1$ & $16.7 \pm 2.9$ & $13.1 \pm 1.3$ \\
\hline 12 & $1(40)$ & $1(400)$ & $-1(0)$ & $1(100)$ & $30.2 \pm 1.6$ & $65.0 \pm 3.7$ & $23.5 \pm 2.2$ & $2.4 \pm 0.1$ & $31.2 \pm 6.8$ & $46.0 \pm 5.9$ & $19.5 \pm 0.6$ \\
\hline 13 & $-1(20)$ & $-1(200)$ & $1(40)$ & $1(100)$ & $31.7 \pm 1.5$ & $73.4 \pm 8.7$ & $16.5 \pm 1.8$ & $6.1 \pm 0.7$ & $1.6 \pm 0.4$ & $261.4 \pm 69.6$ & $7.5 \pm 0.6$ \\
\hline 14 & $1(40)$ & $-1(200)$ & $1(40)$ & $1(100)$ & $26.1 \pm 0.6$ & $64.0 \pm 3.7$ & $21.7 \pm 1.8$ & $7.6 \pm 0.3$ & $1.6 \pm 0.3$ & $318.9 \pm 55.5$ & $10.8 \pm 1.3$ \\
\hline 15 & $-1(20)$ & $1(400)$ & $1(40)$ & $1(100)$ & $37.8 \pm 0.9$ & $79.3 \pm 2.4$ & $16.4 \pm 0.8$ & $2.3 \pm 0.1$ & $22.2 \pm 3.7$ & $30.9 \pm 2.4$ & $12.2 \pm 1.9$ \\
\hline 16 & 1 (40) & $1(400)$ & $1(40)$ & $1(100)$ & $32.2 \pm 0.4$ & $64.2 \pm 1.6$ & $21.8 \pm 0.5$ & $2.4 \pm 0.1$ & $30.9 \pm 3.7$ & $35.8 \pm 2.3$ & $24.8 \pm 2.1$ \\
\hline 17 & $0(30)$ & $0(300)$ & $0(20)$ & $0(50)$ & $36.3 \pm 0.9$ & $76.4 \pm 1.9$ & $16.4 \pm 1.5$ & $2.5 \pm 0.2$ & $69.6 \pm 1.2$ & $33.8 \pm 4.8$ & $12.8 \pm 0.5$ \\
\hline 18 & $0(30)$ & $0(300)$ & $0(20)$ & $0(50)$ & $34.2 \pm 0.5$ & $74.9 \pm 2.2$ & $17.7 \pm 1.3$ & $2.3 \pm 0.3$ & $68.5 \pm 9.1$ & $24.3 \pm 3.7$ & $13.7 \pm 1.5$ \\
\hline 19 & $0(30)$ & $0(300)$ & $0(20)$ & $0(50)$ & $35.8 \pm 0.2$ & $74.1 \pm 1.6$ & $16.7 \pm 1.2$ & $2.2 \pm 0.2$ & $70.1 \pm 16.6$ & $23.7 \pm 1.0$ & $12.8 \pm 0.9$ \\
\hline
\end{tabular}

Note: [P], protein concentration; [G], glycerol concentration; [PE], phenolic extract concentration; [MMT], montmorillonite concentration; TS, tensile strength; YM, Young's modulus; WVP, water vapor permeability.

Table 4. Effect of protein, glycerol, phenolic extract and montmorilonite clay concentration on films properties.

Tabla 4. Efecto de las concentraciones de proteína, de glicerol, de extracto fenólico y de arcilla montmorillonítica en las propiedades de las películas.

\begin{tabular}{|c|c|c|c|c|c|c|c|c|c|c|c|c|c|c|}
\hline \multirow[b]{2}{*}{ Factor } & \multicolumn{2}{|c|}{ Solubility (\%) } & \multicolumn{2}{|c|}{ Lightness (L*) } & \multicolumn{2}{|c|}{ Opacity (\%) } & \multicolumn{2}{|c|}{ TS (MPa) } & \multicolumn{2}{|c|}{ Elongation (\%) } & \multicolumn{2}{|c|}{ YM (MPa) } & \multicolumn{2}{|c|}{$\begin{array}{l}\text { WVP }(\mathrm{g} \cdot \mathrm{mm} / \mathrm{d} \\
\left.\mathrm{m}^{2} . \mathrm{kPa}\right)\end{array}$} \\
\hline & Effect & $p$-value & Effect & $p$-value & Effect & $p$-value & Effect & $p$-value & Effect & $p$-value & Effect & $p$-value & Effect & $p$-value \\
\hline Mean & 32.96 & 0.0001 & 71.83 & $<0.0001$ & 19.04 & 0.0001 & 4.14 & 0.0001 & 29.36 & $<0.0001$ & 151.37 & 0.0001 & 12.87 & 0.0001 \\
\hline$[\mathrm{P}]$ & -5.61 & 0.0093 & -14.82 & 0.0015 & 6.98 & 0.0026 & 0.56 & 0.0212 & 2.97 & 0.0180 & 15.29 & 0.0329 & 5.16 & 0.0025 \\
\hline [G] & 2.70 & 0.0386 & 2.29 & 0.0580 & -1.35 & 0.0629 & -3.51 & 0.0006 & 28.15 & 0.0002 & -248.06 & 0.0001 & 7.18 & 0.0013 \\
\hline$[\mathrm{PE}]$ & 1.58 & 0.1014 & 0.11 & 0.8625 & -2.51 & 0.0196 & 0.93 & 0.0079 & -6.48 & 0.0039 & 127.92 & 0.0005 & 1.68 & 0.0230 \\
\hline [MMT] & 0.02 & 0.9778 & -0.73 & 0.3311 & 0.74 & 0.1721 & -1.12 & 0.0055 & -8.32 & 0.0024 & -120.62 & 0.0006 & 0.49 & 0.1984 \\
\hline$[\mathrm{P}] \times[\mathrm{G}]$ & 1.42 & 0.1215 & -0.73 & 0.3328 & -0.14 & 0.7307 & -0.34 & 0.0545 & 11.00 & 0.0013 & -5.77 & 0.1800 & 3.29 & 0.0062 \\
\hline$[\mathrm{P}] \times[\mathrm{PE}]$ & 1.24 & 0.1515 & 2.16 & 0.0648 & -1.75 & 0.0391 & -0.87 & 0.0090 & 4.86 & 0.0068 & -18.64 & 0.0225 & 1.16 & 0.0469 \\
\hline$[\mathrm{P}] \times[\mathrm{MMT}]$ & -1.09 & 0.1842 & -0.16 & 0.8086 & 0.36 & 0.4187 & 0.71 & 0.0135 & -4.05 & 0.0098 & 30.06 & 0.0088 & 0.86 & 0.0797 \\
\hline$[\mathrm{G}] \times[\mathrm{PE}]$ & 1.17 & 0.1659 & -0.41 & 0.5501 & 1.15 & 0.0836 & -1.20 & 0.0048 & 6.27 & 0.0041 & -149.58 & 0.0004 & 0.51 & 0.1892 \\
\hline$[\mathrm{G}] \times[\mathrm{MMT}]$ & 2.51 & 0.0442 & 0.35 & 0.6044 & 0.30 & 0.4902 & -0.01 & 0.9109 & -5.75 & 0.0049 & 84.05 & 0.0011 & 1.44 & 0.0308 \\
\hline$[\mathrm{PE}] \times[\mathrm{MMT}]$ & -2.72 & 0.0379 & -1.36 & 0.1420 & 1.07 & 0.0954 & 0.48 & 0.0290 & -0.76 & 0.2005 & -33.12 & 0.0073 & -0.19 & 0.5399 \\
\hline
\end{tabular}

Note: [P], protein concentration; [G], glycerol concentration; [PE], phenolic extract concentration; [MMT], montmorillonite concentration; TS, tensile strength; YM, Young's modulus; WVP, water vapor permeability.

\section{Effect of protein concentration on films properties}

The inherent properties of proteins make them excellent materials for films productions. The distribution of charged, polar and non-polar amino acids along the protein chain creates a potential chemical interaction between materials, resulting in a cohesive protein film matrix. Films are formed and stabilized through electrostatic interactions, hydrogen bonding, van der Waals forces, covalent bonding and disulfide bridges (Dangaran et al., 2009). Table 4 shows that protein concentration was the most important factor affecting solubility of the films, resulting in a decrease of $10 \%$ in solubility values, being obtained some films with solubility below $25 \%$. This behavior is explained by the increasing protein-protein interactions caused by the presence of intermolecular disulfide bonds (Gounga, Xu, \& Wang, 2007). However, films' solubility values were lower than those obtained from other protein sources such as whey (Ozdemir \& Floros, 2008), soy protein isolate and cod gelatin (Denavi et al., 2009), which presented minimal solubility values of $37 \%, 84 \%$ and $87 \%$, respectively.

Opacity is indicative of the light passing through a material (Lima et al., 2010) and can be used to control the incidence of light on a food protecting it against oxidative processes. Protein concentration was the factor that most affected the optical properties of the films, being the only factor that affected luminosity $(p<0.05)$. Luminosity values of the films were similar to those reported by Guerrero, Stefani, Ruseckaite, and Caba (2011) for 
Table 5. ANOVA of the films properties using a confidence interval of $95 \%$.

Tabla 5. Análisis de varianza ANOVA de las propiedades de las películas utilizando un intervalo de confianza de $95 \%$.

\begin{tabular}{|c|c|c|c|c|c|c|}
\hline Properties & $\begin{array}{l}\text { Sources of } \\
\text { variations }\end{array}$ & SS & DF & MS & $F$ ratio & $R^{2}$ \\
\hline \multirow[t]{3}{*}{ Solubility (\%) } & Regression & 209.55 & 4 & 52.39 & \multirow[t]{3}{*}{2.33} & \multirow[t]{3}{*}{0.67} \\
\hline & Residual & 101.31 & 14 & 7.24 & & \\
\hline & Total & 310.86 & & & & \\
\hline \multirow[t]{3}{*}{ Lightness $\left(\mathrm{L}^{*}\right)$} & Regression & 877.94 & 1 & 877.94 & \multirow[t]{3}{*}{29.08} & \multirow[t]{3}{*}{0.88} \\
\hline & Residual & 115.31 & 17 & 6.78 & & \\
\hline & Total & 993.25 & & & & \\
\hline \multirow[t]{3}{*}{ Opacity (\%) } & Regression & 232.19 & 3 & 77.40 & \multirow[t]{3}{*}{8.91} & \multirow[t]{3}{*}{0.85} \\
\hline & Residual & 39.64 & 15 & 2.64 & & \\
\hline & Total & 271.83 & & & & \\
\hline \multirow{3}{*}{$\begin{array}{l}\text { Tensile } \\
\text { strength } \\
\text { (MPa) }\end{array}$} & Regression & 70.77 & 8 & 8.85 & \multirow[t]{3}{*}{2.08} & \multirow[t]{3}{*}{0.84} \\
\hline & Residual & 13.84 & 10 & 1.38 & & \\
\hline & Total & 84.61 & & & & \\
\hline \multirow{3}{*}{$\begin{array}{c}\text { Elongation } \\
(\%)\end{array}$} & Regression & 4582.66 & 9 & 509.18 & \multirow[t]{3}{*}{0.24} & \multirow[t]{3}{*}{0.44} \\
\hline & Residual & 5937.78 & 9 & 659.75 & & \\
\hline & Total & 10520.44 & & & & \\
\hline \multirow{3}{*}{$\begin{array}{l}\text { Young's } \\
\text { modulus } \\
(\mathrm{MPa})\end{array}$} & Regression & 497870.18 & 9 & 55318.91 & \multirow[t]{3}{*}{2.23} & \multirow[t]{3}{*}{0.88} \\
\hline & Residual & 70322.45 & 9 & 7813.61 & & \\
\hline & Total & 568192.63 & & & & \\
\hline \multirow{3}{*}{$\begin{array}{l}\text { WVP }(\mathrm{g} \cdot \mathrm{mm} / \\
\left.\text { d.m } \mathrm{m}^{2} \cdot \mathrm{kPa}\right)\end{array}$} & Regression & 380.92 & 6 & 63.49 & \multirow[t]{3}{*}{14.70} & \multirow[t]{3}{*}{0.96} \\
\hline & Residual & 17.30 & 12 & 1.44 & & \\
\hline & Total & 398.22 & & & & \\
\hline
\end{tabular}

Note: Where: SS, sum of squares; DF, degrees of freedom; MS, mean square; $F$ ratio, relation between test $F$ value and $F$ of Fisher's value at $95 \%$ confidence interval; WVP, water vapor permeability.

soy protein isolate films, with a yellowish tonality (chromaticity coordinate $b^{*+}$, data not included).

The increase in protein concentration in the film forming solutions had positive effects $(p<0.05)$ on the mechanical properties and water vapor permeability of the resulting films. Proteins are very different depending on the origin, structure and amino acid composition. Protein-protein interactions involved in film formation determine the degree of crosslinking and their hydrophilic/hydrophobic properties and are also related to the physicochemical, mechanical and barrier properties of the films (Denavi et al., 2009).

\section{Effect of glycerol concentration}

Production of protein-based films generally needs the incorporation of a minimal content of plasticizer. Plasticizers act by weakening intermolecular forces between adjacent polymer chains of protein matrix reducing its brittleness. This incorporation results in an increase of film extensibility and flexibility while decreases the elasticity, mechanical resistance and barrier property of the films (Gounga et al., 2007). These modifications are shown in this study (Table 4), where the increase of glycerol concentration changes the solubility, WVP and mechanical properties of the films. The effect of glycerol on the solubility of rice bran protein films was also verified by Adebiyi et al. (2008), who found that increasing the concentration of glycerol can open the polymer structure and enhance the permeability of moisture at higher concentrations.

Addition of glycerol produced a negative effect on TS, leading to a decrease of $3.5 \mathrm{MPa}$, while its interaction with proteins promoted a positive effect on $\% \mathrm{E}$. With respect to elasticity (YM), the increase of glycerol concentration resulted in weakening of the connections between molecules, reducing films elasticity. The effect of increasing concentrations of glycerol on mechanical properties of biodegradable films was also reported by Cao et al. (2007), who observed that the tension and elasticity decreased while elongation increased.

With respect to WVP, the glycerol content should be the lowest possible to avoid moisture transfer between the food and the external atmosphere (Dias, Muller, Larotonda, \& Laurindo, 2010). The WVP of films was mainly affected by glycerol and protein concentrations (Table 4). Increasing the concentration of these components, an increase of WVP values of the films were promoted; moreover, the interaction between these two variables also caused an increase of the permeation rate. Similar results were observed by Kokoszka, Debeaufort, Hambleton, Lenart, and Voilley (2010) for soy protein-based films. The lower values of WVP (below $7.5 \mathrm{~g} . \mathrm{mm} / \mathrm{d} . \mathrm{m}^{2} . \mathrm{kPa}$ ) were obtained at low protein and glycerol concentrations (Figure 1a). An increase in the concentration of plasticizer generally causes an increase in films' WVP due to reorganization of the protein network and consequent increase in free volume (Dias et al., 2010; Gounga et al., 2007).

\section{Effect of phenolic extract concentration}

Phenolic compounds derived from rice bran fermentation have antioxidant and antimicrobial activity (Oliveira et al., 2007; M. Souza et al., 2010). The extract phenolic content added to the films, on the level of the highest concentration, was estimated upon the maximum that protein in solution could support without precipitating these proteins. This corresponded to about 25 times greater than the $\mathrm{EC}_{50}$ value of the extract phenolic (Schmidt et al., 2014). Therefore, antioxidant and antimicrobial effects should be expected. However, the inclusion of an additive can modify the properties of edible films due to the physical changes induced in the film's structure, promoting changes in polymer-polymer interactions, reacting at more than one site on the protein structure and inducing cross-links between proteins (Dangaran et al., 2009). Table 4 shows the effect of the addition of phenolic extract in films properties.

Optical, mechanical and WVP properties were affected by increasing phenolic extract, that in interaction with the protein concentration also affects the films' opacity $(p<0.05)$. The highest opacity value $(27 \%)$ was obtained at lower phenolic extract concentrations and higher protein concentrations (Figure 1b).

Phenolic extract addition leads to a positive effect on TS and a negative effect on $\% \mathrm{E}$, being also the factor that most contributed to increase of YM values of films (Table 4). Figure 1c shows that the elasticity of films was greater for higher phenolic extract concentrations and lower glycerol concentrations, with values above $600 \mathrm{MPa}$, much higher than those found for films with soy protein isolate and gelatin, whose maxima were around $160 \mathrm{MPa}$ (Guerrero et al., 2011).

The addition of phenolic extract to films caused a significant increase $(p<0.05)$ of WVP values (Table 4$)$ explained by the increase of hydrophilicity of the films with the addition of phenolic extracts. Similar behavior was observed by Ou, Wang, Tang, Huang, and Jackson (2005).

\section{Effect of MMT concentration}

MMT can form stable suspensions in water due to its hydrophilic character. This property of MMT facilitates its dispersion in water soluble polymers (Tunç \& Duman, 2010). Various authors have used MMT in films preparation, aiming the improvement of their physical properties. Tunç and Duman (2010) developed 
(a)

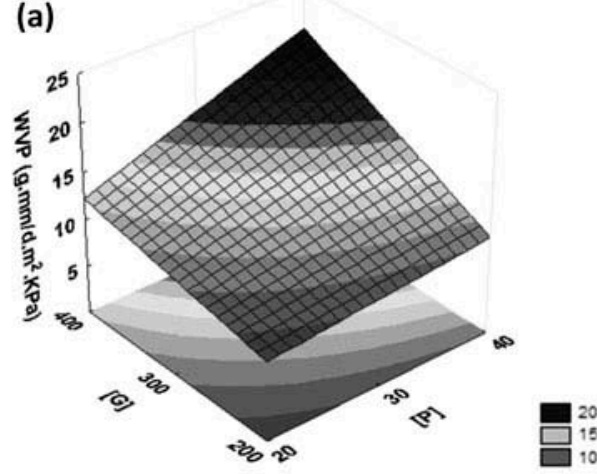

$W V P=12.87+2.58^{*}[P]+3.59^{*}[G]+0.84^{*}[P E]+1.65 *[P] \times[G]+$ $0.58^{*}[\mathrm{P}] \times[\mathrm{PE}]+0.72^{*}[\mathrm{G}] \times[\mathrm{MMT}]$ $R=0.98 ; F / F_{\text {Fisher }}=14.7$

(c)

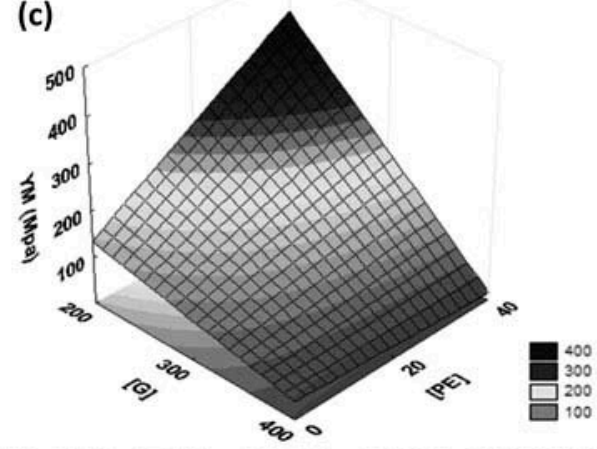

$Y M=151.37+7.65^{*}[\mathrm{P}]-124.03^{*}[\mathrm{G}]+63.96^{*}[\mathrm{PE}]-60.31^{*}[\mathrm{MMT}]-$ $9.32^{*}[\mathrm{P}] \times[\mathrm{PE}]+15.03^{*}[\mathrm{P}] \times[\mathrm{MMT}]-74.79^{*}[\mathrm{G}] \times[\mathrm{PE}]+42.03^{*}[\mathrm{G}] \times[\mathrm{MMT}]$ $-16.56^{*}[\mathrm{PE}] \times[\mathrm{MMT}]$ $R=0.94 ; F / F_{\text {pldef }}=2.2$ (b)

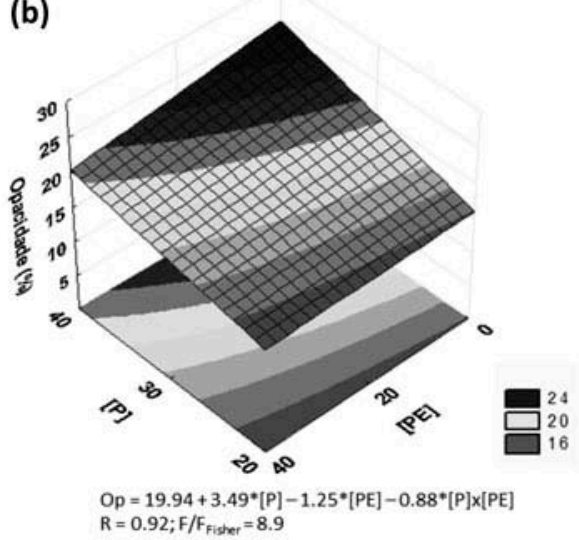

(d)

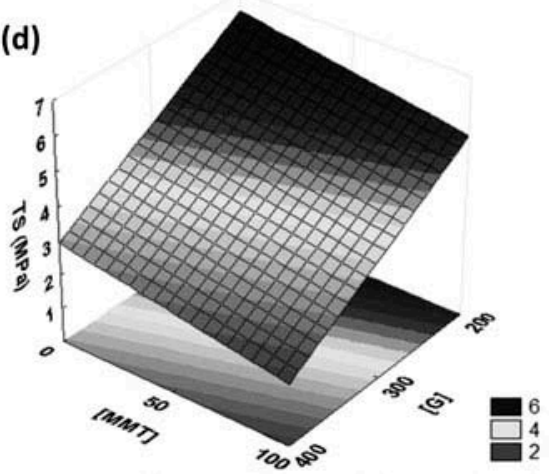

$\mathrm{TS}=4.14+0.28^{*}[\mathrm{P}]-1.75^{*}[\mathrm{G}]+0.47 *[\mathrm{PE}]-0.56^{*}[\mathrm{MMT}]-$ $0.44^{*}[\mathrm{P}] \times[\mathrm{PE}]+0.36^{*}[\mathrm{P}] \times[\mathrm{MMT}]-0.60^{*}[\mathrm{G}] \times[\mathrm{PE}]+0.24^{*}[\mathrm{PE}] \times[\mathrm{MMT}]$ $\mathrm{R}=0.91 ; \mathrm{F} / \mathrm{F}_{\text {Figler }}=2.1$

Figure 1. Response surfaces that relate: (a) water vapor permeability with protein and glycerol concentrations; (b) opacity with protein and phenolic extract concentrations; (c) Young's modulus with glycerol and phenolic extract concentrations; (d) tensile strength with glycerol and MMT clay, where: [P], protein concentration $(\mathrm{g} / \mathrm{L})$; $[\mathrm{G}]$, glycerol concentration $\left(\mathrm{g} / \mathrm{kg}_{\text {protein }}\right)$; [PE], phenolic extract concentration $\left(\mathrm{g} / \mathrm{kg}_{\text {protein }}\right)$; [MMT], montmorillonite concentration $\left(\mathrm{g} / \mathrm{kg}_{\text {protein }}\right)$; TS, tensile strength; YM, Young modulus; WVP, water vapor permeability. R, correlation coefficient; $F$, value $F$ of mathematic model;

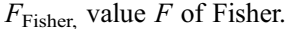

Figura 1. Superficies de respuesta que relacionan: (a) la permeabilidad al vapor de agua con concentraciones de proteína y de glicerol; (b) la opacidad con concentraciones de extractos proteicos y fenólicos; (c) los módulos de Young con concentraciones de extracto fenólico y de glicerol; (d) la fuerza de tensión con el glicerol y la arcilla montmorillonítica. Donde: $[\mathrm{P}]$, concentración proteica $(\mathrm{g} / \mathrm{L})$; $[\mathrm{G}]$, concentración de glicerol ( $\mathrm{g} / \mathrm{kg}_{\text {protein }}$ ); [PE], concentración de extracto fenólico ( $\left.\mathrm{g} / \mathrm{kg}_{\text {protein }}\right)$; [MMT], concentración montmorillonítica $\left(\mathrm{g} / \mathrm{kg}_{\text {protein }}\right.$ ); TS, fuerza de tensión; YM, módulos de Young;

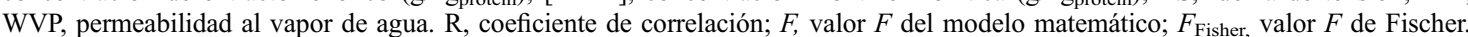

gluten-based films with the addition of MMT and highlighted that the presence of MMT induced reduction of the water sensitivity of the films. Lee and Kim (2010) developed composite films of soy protein isolate and MMT and obtained better mechanical and permeability properties when compared with films without MMT.

The addition of MMT to the films negatively affected $(p<0.05)$ mechanical properties (Table 4$)$, once higher values of TS (8.6 MPa) were obtained without the addition of MMT and for lower glycerol concentrations (Figure 1d). MMT addition at the levels reported here did not affect $(p<0.05)$ the other properties, only its interactions with glycerol increased solubility and WVP of films, while the interaction with the phenolic extract decreased solubility of the films.

MMT is a type of clay that has been used in the preparation of biodegradable films in order to improve their mechanical properties (Chen \& Zhang, 2006). In this study the use of clay MMT showed no significant improvements in the films' properties for the reported concentrations. This can be explained by the incomplete exfoliation of the clay in the film forming solution, difficult because of the wide lateral dimension of the layers, due to high intrinsic viscosity of the polymer and the strong tendency of clay tactoids to agglomerate (Ray \& Bousmina, 2005; Zhu \& Wool, 2006).

\section{Scanning electron microscopy}

The microscopic observation of the surface of the films provides information on the integrity, continuity and also about the structural organization of the filmogenic polymeric matrix (Souza, Cerqueira, Teixeira, \& Vicente, 2010). The surface of the films produced only with rice bran protein at low glycerol concentration showed no visibly different structural characteristics when compared to the films with phenolic extract (Figure 2a and b), where pinholes were observed on the surface, possibly due to air bubbles. Some irregularities were also observed on their surfaces, possibly due to the presence of more than one macromolecule in the polymer matrix. The RBPC had about $25 \%$ of polysaccharides in its composition (Table 2), which could 


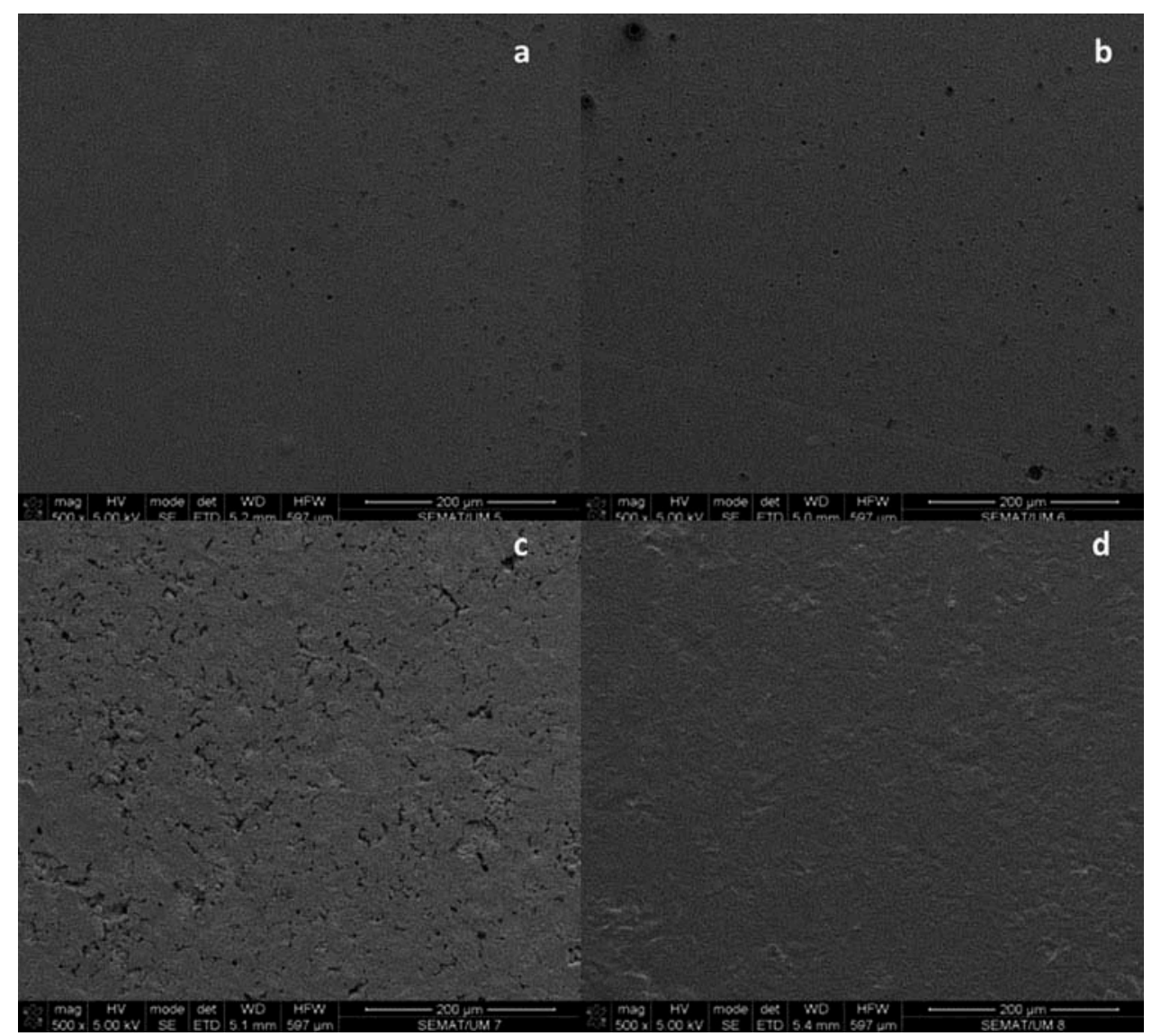

Figure 2. SEM images of surface of rice bran protein films developed from formulations containing: $20 \mathrm{~g} / \mathrm{L}$ of protein and $200 \mathrm{~g} / \mathrm{kg}_{\text {protein }}$ of glycerol (a); $20 \mathrm{~g} / \mathrm{L}$ of protein and $200 \mathrm{~g} / \mathrm{kg}_{\text {protein }}$ of glycerol and $40 \mathrm{~g} / \mathrm{kg}_{\text {protein }}$ of phenolic extract (b); $20 \mathrm{~g} / \mathrm{L}$ of protein and $200 \mathrm{~g} / \mathrm{kg}_{\text {protein }}$ of glycerol and $100 \mathrm{~g} /$ $\mathrm{kg}_{\text {protein }}$ of MMT (c); $30 \mathrm{~g} / \mathrm{L}$ of protein and $300 \mathrm{~g} / \mathrm{kg}_{\text {protein }}$ of glycerol and $20 \mathrm{~g} / \mathrm{kg}_{\text {protein }}$ of phenolic extract and $50 \mathrm{~g} / \mathrm{kg}_{\text {protein }}$ of MMT (d).

Figura 2. Imágenes SEM de la superficie de las películas de proteína de salvado de arroz desarrolladas de fórmulas que contienen: $20 \mathrm{~g} / \mathrm{L}$ de proteína y $200 \mathrm{~g} / \mathrm{kg}_{\text {protein }}$ de glicerol (a); $20 \mathrm{~g} / \mathrm{L}$ de proteína y $200 \mathrm{~g} / \mathrm{kg}_{\text {protein }}$ of glicerol y $40 \mathrm{~g} / \mathrm{kg}_{\text {protein }}$ de extracto fenólico (b); $20 \mathrm{~g} / \mathrm{L}$ de proteína y $200 \mathrm{~g} / \mathrm{kg}_{\text {protein }}$ de glicerol y $100 \mathrm{~g} / \mathrm{kg}_{\text {protein }}$ de MMT (c); $30 \mathrm{~g} / \mathrm{L}$ de proteína y $300 \mathrm{~g} / \mathrm{kg}_{\text {protein }}$ de glicerol y $20 \mathrm{~g} / \mathrm{kg}_{\text {protein }}$ de extracto fenólico y $50 \mathrm{~g} / \mathrm{kg}_{\text {protein }}$ de $\mathrm{MMT}$ (d).

influence the films' homogeneity. A similar effect was reported by Dias et al. (2010) in rice flour films.

MMT addition to the films in concentrations of $5 \% \mathrm{w} / \mathrm{v}$ appear to correct some imperfections (Figure 2d), decreasing the porosity and forming a denser surface; however, concentrations of $10 \% \mathrm{w} / \mathrm{v}$ induced excessive cracks on the surfaces of the films (Figure 2c) which confirms the negative effects produced in $\mathrm{TS}, \% \mathrm{E}$ and $\mathrm{YM}$ (Table 4). When the clay is found in high concentrations, some of it may not establish interactions with the protein, being subject to loss of water during drying, thus causing cracks in the surface of the films.

\section{FTIR spectroscopy}

Infrared spectroscopy is a rapid and a non-destructive technique that has been widely used to characterize different biomaterials. Moreover, FTIR spectroscopy is a powerful technique to evaluate polymer blend miscibility. When chemical groups interact at the molecular level, changes are seen in FTIR spectra such as the shifting of absorption bands. These changes can be an indication of good miscibility of polymers as well of other chemical interactions. In this work, FTIR showed that the absorption spectra of films from different formulations had similar absorption regions, differing only in the bands' absorption intensity. Films with phenolic extract (Figure 3c) showed higher absorptions across the spectrum when compared to films without phenolic extract (Figure 3b), indicating a greater interaction of compounds explained by the presence of hydroxyls that increase the number of hydrogen bonds in the protein matrix. Absorption bands at 1600 and $1520 \mathrm{~cm}^{-1}$ can be attributed to $\mathrm{C}=\mathrm{C}$ bond vibrations typical of aromatic systems. A strong contribution of the $-\mathrm{OH}$ deformation can be found in the region $1410-1260 \mathrm{~cm}^{-1}$. Strong valence vibrations between 1150 and $1040 \mathrm{~cm}^{-1}$ overlap aromatic impressions of bands at $1225-950 \mathrm{~cm}^{-1} . \mathrm{CH}_{3}$ symmetric deformation vibrations occur in the region 1190-1370 $\mathrm{cm}^{-1}$ (Edelmann, Diewok, Schuster, \& Lendl, 2001). These bands coincided with the bands presented by the RBPC (Figure 3a).

On the contrary, addition of MMT to the films decreased absorption peaks over the whole range of the spectrum (Figure $3 d$ ), especially in the region around $3400 \mathrm{~cm}^{-1}$ and between 1700 and $1500 \mathrm{~cm}^{-1}$, regions which are characteristic of $-\mathrm{NH}$ absorption groups of the amino acids and amide I and II bands of proteins, indicating the interaction of MMT with these protein groups which results in a reduced vibration of these functional groups of proteins.

The spectra in the infrared region are commonly influenced by the contribution of various vibrational modes between 3000 and $3700 \mathrm{~cm}^{-1}$ and below $1700 \mathrm{~cm}^{-1}$. Due to this, glycerol and MMT 

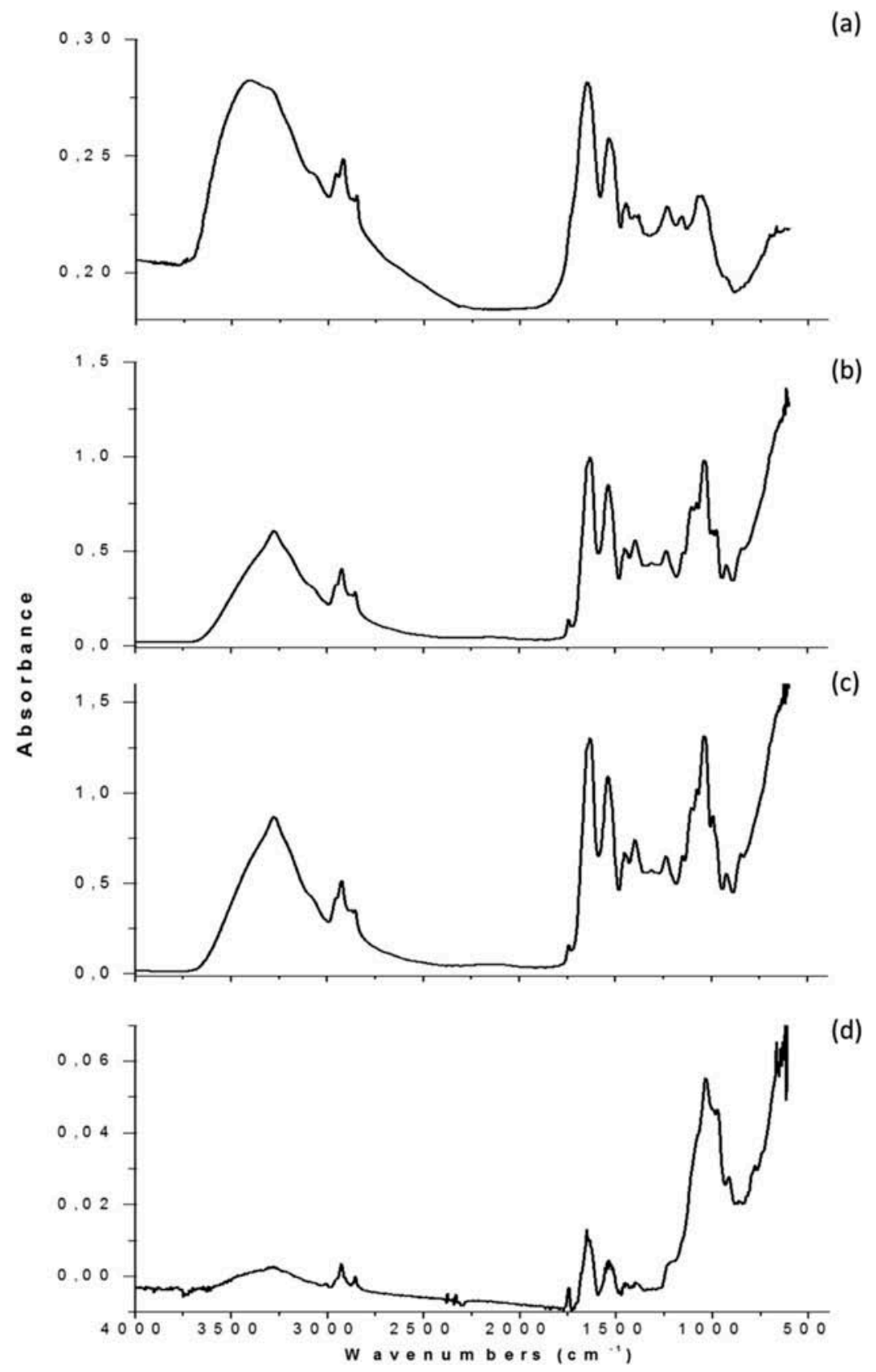

(d)

Figure 3. FTIR spectra of rice bran protein concentrated (a) and rice bran protein films developed from formulations containing $20 \mathrm{~g} / \mathrm{L}$ of protein and $200 \mathrm{~g} / \mathrm{kg}_{\text {protein }}$ of glycerol (b); $20 \mathrm{~g} / \mathrm{L}$ of protein and $200 \mathrm{~g} / \mathrm{kg}_{\text {protein }}$ of glycerol and $40 \mathrm{~g} / \mathrm{kg}_{\text {protein }}$ of phenolic extract (c); $20 \mathrm{~g} / \mathrm{L}$ of protein and $200 \mathrm{~g} /$ $\mathrm{kg}_{\text {protein }}$ of glycerol and $100 \mathrm{~g} / \mathrm{kg}_{\text {protein }}$ of MMT (d).

Figura 3. Espectro FTIR de concentrado de proteína de salvado de arroz (a) y películas de proteína de salvado de arroz desarrolladas a partir de fórmulas que contienen: $20 \mathrm{~g} / \mathrm{L}$ de proteína y $200 \mathrm{~g} / \mathrm{kg}_{\text {protein }}$ de glicerol (b); $20 \mathrm{~g} / \mathrm{L}$ de proteína y $200 \mathrm{~g} / \mathrm{kg}_{\text {protein }}$ de glicerol y $40 \mathrm{~g} / \mathrm{kg}_{\text {protein }}$ de extracto fenólico (c); $20 \mathrm{~g} / \mathrm{L}$ de proteína y $200 \mathrm{~g} / \mathrm{kg}_{\text {protein }}$ de glicerol y $100 \mathrm{~g} / \mathrm{kg}_{\text {protein }}$ de MMT (d).

could not be identified because their vibrational modes are overlapped by several bands from protein and phenolic compounds.

Rice bran protein films showed distinct characteristics, which may find application in the production of biodegradable packaging and protective films. Their use as edible coatings has been evaluated as a good alternative for preservation of whole or minimally processed fruits and vegetables, since these coatings can create a semi-permeable barrier to gases and water vapor, maintaining product quality, as well as being potential carriers for additives to help preserve or even improve the quality of the product (Dangaran et al., 2009; Olivas \& Barbosa-Canovas, 2009).

\section{Conclusions}

The best properties were obtained for rice bran protein films with lower protein and glycerol concentrations and with addition of phenolic extract without the presence of MMT clay. Protein concentration was the factor that most affected solubility, luminosity and opacity these films. The mechanical properties of the films were affected by glycerol concentration, while the addition of phenolic extract to the films affected opacity, tensile strength, elongation, Young's modulus and water vapor permeability. Due to not fully exfoliated, the addition of MMT not favored the mechanical properties of the films. The obtained films could be 
applied as packaging material for fruits and vegetables, whole or minimally processed.

\section{Acknowledgements}

Authors Cristiano G. Schmidt and Miguel A. Cerqueira are thankful to Coordenação de Aperfeiçoamento de Pessoal de Nível Superior (CAPES, Brazil; BEX 9730/11-7) and Fundação para a Ciência e Tecnologia, POPH-QREN and FSE (FCT, Portugal) (SFRH/BPD/ 72753/2010) for financial support. The authors thank the FCT Strategic Project PEst-OE/EQB/LA0023/2013 and the project "Biolnd -Biotechnology and Bioengineering for improved Industrial and Agro-Food processes", REF.NORTE-07-0124FEDER-000028 Co-funded by the Programa Operacional Regional do Norte (ON.2 - O Novo Norte), QREN, FEDER.

\section{References}

Adebiyi, A. P., Adebiyi, A. O., Jin, D. H., Ogawa, T., \& Muramoto, K (2008). Rice bran protein-based edible films. International Journal of Food Science and Technology, 43, 476-483. doi:10.1111/j.13652621.2006.01475.x

Andreuccetti, C., Rosemary, A. C., Galicia-García, T., Martínez-Bustos, F., \& Grosso, C. R. F. (2011). Effect of surfactants on the functional properties of gelatin-based edible films. Journal of Food Engineering, 103, 129-136. doi:10.1016/j.jfoodeng.2010.10.007

AOAC. (2000). Official methods of analysis (17th ed.). Washington, DC: Association of Official Analytical Chemists.

ASTM. (2001). Standard test method for tensile properties of thin plastic sheeting (D882-02). In ASTM International (Ed.), Annual book of ASTM standards. Philadelphia, PA: American Society for Testing and Materials.

Cao, N., Fu, Y., \& He, J. (2007). Preparation and physical properties of soy protein isolate and gelatin composite films. Food Hydrocolloids, 21, 1153-1162. doi:10.1016/j.foodhyd.2006.09.001

Carvalho, R. A., \& Grosso, C. R. F. (2006). Efeito do tratamento térmico e enzimático nas propriedades de filmes de gelatina. Ciência e Tecnologia de Alimentos, 26, 495-501. doi:10.1590/S0101-20612006000300002

Chen, P., \& Zhang, L. (2006). Interaction and properties of highly exfoliated soy protein/montmorillonite nanocomposites. Biomacromolecules, 7, 1700-1706. doi:10.1021/bm050924k

Cipolatti, E. P., Kupski, L., Rocha, M., Oliveira, M. S., Buffon, J. G., \& Furlong, E. B. (2012). Application of protein-phenolic based coating on tomatoes (Lycopersicum esculentum). Food Science and Technology (Campinas), 32, 594-598. doi:10.1590/S0101-20612012005000081

Dangaran, K., Tomasula, P. M., \& Qi, P. (2009). Structure and function of protein-based edible films and coatings. In M. E. Embuscado \& K. C. Huber (Eds.), Edible films and coatings for food applications (pp. 25-56). New York, NY: Springer.

Denavi, G. A., Pérez-Mateos, M., Añón, M. C., Montero, P., Mauri, A N., \& Gómez-Guillén, M. C. (2009). Structural and functional properties of soy protein isolate and cod gelatin blend films. Food Hydrocolloids, 23, 2094-2101. doi:10.1016/j.foodhyd.2009.03.007

Dias, A. B., Muller, C. M. O., Larotonda, F. D. S., \& Laurindo, J. B. (2010) Biodegradable films based on rice starch and rice flour. Journal of Cereal Science, 51, 213-219. doi:10.1016/j.jcs.2009.11.014

Edelmann, A., Diewok, J., Schuster, K. C., \& Lendl, B. (2001). Rapid method for the discrimination of red wine cultivars based on mid-infrared spectroscopy of phenolic wine extracts. Journal of Agricultural and Food Chemistry, 49, 1139-1145. doi:10.1021/jf001196p

Fakhouri, F. M., Fontes, L. C. B., Gonçalves, P. V. M., Milanez, C. R., Steel, C. J., \& Collares-Queiroz, F. P. (2007). Filmes e coberturas comestíveis compostas à base de amidos nativos e gelatina na conservação e aceitação sensorial de uvas Crimson. Ciência e Tecnologia de Alimentos, 27, 369-375. doi:10.1590/S0101-20612007000200027

Gounga, M. E., Xu, S., \& Wang, Z. (2007). Whey protein isolate-based edible films as affected by protein concentration, glycerol ratio and pullulan addition in film formation. Journal of Food Engineering, 83, 521-530. doi:10.1016/j.jfoodeng.2007.04.008

Guerrero, P., Stefani, P. M., Ruseckaite, R. A., \& Caba, K. (2011) Functional properties of films based on soy protein isolate and gelatin processed by compression molding. Journal of Food Engineering, 105, 65-72. doi:10.1016/j.jfoodeng.2011.02.003

Kokoszka, S., Debeaufort, F., Hambleton, A., Lenart, A., \& Voilley, A. (2010). Protein and glycerol contents affect physico-chemical properties of soy protein isolate-based edible films. Innovative Food Science and Emerging Technologies, 11, 503-510. doi:10.1016/j.ifset.2010.01.006

Lee, J. E., \& Kim, K. M. (2010). Characteristics of soy protein isolatemontmorillonite composite films. Journal of Applied Polymer Science, 118, 2257-2263.

Lima, A. M., Cerqueira, M. A., Souza, B. W. S., Santos, E. C. M., Teixeira, J. A., Moreira, R. A., \& Vicente, A. A. (2010). New edible coatings composed of galactomannans and collagen blends to improve the postharvest quality of fruits - Influence on fruits gas transfer rate. Journal of Food Engineering, 97, 101-109. doi:10.1016/j.jfoodeng.2009.09.021

Martins, J. T., Bourbon, A. I., Pinheiro, A. C., Souza, B. W. S., Cerqueira, M. A., \& Vicente, A. A. (2012). Biocomposite films based on $\kappa$-carrageenan/locust bean gum blends and clays: Physical and antimicrobial properties. Food and Bioprocess Technology. doi:10.1007/s11947-012-0851-4.

Montgomery, D. C. (1991). Design and analysis of experiments (3rd ed.). New York, NY: John Wiley.

Olivas, G. I., \& Barbosa-Canovas, G. V. (2009). Edible films and coatings for fruits and vegetables. In M. E. Embuscado \& K. C. Huber (Eds.), Edible films and coatings for food applications (pp. 211244). New York, NY: Springer.

Oliveira, M. S., Dors, G. C., Souza-Soares, L. A., \& Furlong, E. B. (2007). Atividade antioxidante e antifúngica de extratos vegetais. Alimentos e Nutrição, 18, 267-275.

Oliveira, M. S., Feddern, V., Kupski, L., Cipolatti, E. P., Badiale-Furlong, E., \& Souza-Soares, L. A. (2011). Changes in lipid, fatty acids and phospholipids composition of whole rice bran after solid-state fungal fermentation. Bioresource Technology, 102, 8335-8338. doi:10.1016/j.biortech.2011.06.025

Ou, S., Wang, Y., Tang, S., Huang, C., \& Jackson, M. G. (2005). Role of ferulic acid in preparing edible films from soy protein isolate. Journal of Food Engineering, 70, 205-210. doi:10.1016/j.jfoodeng.2004.09.025

Ozdemir, M., \& Floros, J. D. (2008). Optimization of edible whey protein films containing preservatives for water vapor permeability, water solubility and sensory characteristics. Journal of Food Engineering, 86, 215-224. doi:10.1016/j.jfoodeng.2007.09.028

Pourali, O., Asghari, F. S., \& Yoshida, H. (2010). Production of phenolic compounds from rice bran biomass under subcritical water conditions. Chemical Engineering Journal, 160, 259-266. doi:10.1016/j. cej.2010.02.057

Ray, S. S., \& Bousmina, M. (2005). Biodegradable polymers and their layered silicate nanocomposites: In greening the 21 st century materials world. Progress in Materials Science, 50, 962-1079. doi:10.1016/j.pmatsci.2005.05.002

Rojas-Grau, M. A., Soliva-Fortuny, R., \& Martín-Belloso, O. (2009). Edible coatings to incorporate active ingredients to fresh cut fruits: A review. Trends in Food Science \& Technology, 20, 438-447. doi:10.1016/j.tifs.2009.05.002

Schmidt, C. G., \& Furlong, E. B. (2012). Effect of particle size and ammonium sulfate concentration on rice bran fermentation with the fungus Rhizopus oryzae. Bioresource Technology, 123, 36-41. doi:10.1016/j.biortech.2012.07.081

Schmidt, C. G., Gonçalves, L. M., Prietto, L., Hackbart, H. S., \& Furlong, E. B. (2014). Antioxidant activity and enzyme inhibition of phenolic acids from fermented rice bran with fungus Rizhopus oryzae. Food Chemistry, 146, 371-377. doi:10.1016/j.foodchem.2013.09.101

Souza, B. W. S., Cerqueira, M. A., Teixeira, J. A., \& Vicente, A. A. (2010). The use of electric fields for edible coatings and films development and production: A review. Food Engineering Reviews, 2, 244-255. doi:10.1007/s12393-010-9029-x

Souza, M. M., Oliveira, M. S., Rocha, M., \& Furlong, E. B. (2010). Avaliação da atividade antifúngica de extratos fenólicos de cebola, farelo de arroz e microalga Chlorella phyrenoidosa. Ciência $e$ Tecnologia de Alimentos, 30, 680-685. doi:10.1590/S010120612010000300018

Tunc, S., Angellier, H., Cahyana, Y., Chalier, P., Gontard, N., \& Gastaldi, E. (2007). Functional properties of wheat gluten/montmorillonite nanocomposite films processed by casting. Journal of Membrane Science, 289, 159-168. doi:10.1016/j.memsci.2006.11.050

Tunç, S., \& Duman, O. (2010). Preparation and characterization of biodegradable methyl cellulose/montmorillonite nanocomposite films. Applied Clay Science, 48, 414 424. doi:10.1016/j.clay.2010.01.016

Zhu, L., \& Wool, R. P. (2006). Nanoclay reinforced bio-based elastomers: Synthesis and characterization. Polymer, 47, 8106-8115. doi:10.1016/j.polymer.2006.07.076 